\title{
$\begin{array}{lllllllll}\mathrm{I} & \mathrm{N} & \mathrm{S} & \mathrm{T} & \mathrm{I} & \mathrm{T} & \mathrm{U} & \mathrm{T} & \mathrm{E}\end{array}$
}

\section{Young Child Poverty in 2009: Rural Poverty Rate Jumps to Nearly 29 Percent in Second Year of Recession}

\author{
MARYBETH J.MATTINGLY AND MICHELLE L. STRANSKY
}

$\mathrm{A}$ merican Community Survey (ACS) data released by the U.S. Census Bureau on September 28, 2010, reveal the impact of the recession on children, particularly young children under the age of 6 . For many young children, the likelihood of living in poverty increased significantly since 2007 and 2008. Also striking is the very high rate of young child poverty experienced by those in the rural South: more than three out of ten young children in the rural southern United States are poor, and the poverty rate increased by over two percentage points to 33.3 percent for these children. Nearly 29 percent of young children in rural America are living in poverty.

Although all children suffer consequences of being poor, young children are especially vulnerable. ${ }^{1}$ The consequences of early poverty ripple through the life cycle for many children. Childhood health problems often follow into adulthood, and early childhood poverty is correlated with fewer years of completed schooling. ${ }^{2}$

While changes from 2008 through 2009 are important, they cannot fully reflect the impact of the recent recession. By looking back not only to 2008, but also to 2007, we get a broader perspective on how poverty rates have changed during the current recession. Experts also predict that with continued high unemployment, poverty rates will continue to rise through 2010 and $2011 .^{3}$

Table 1 is restricted to very young children and estimates of those in poverty and poverty rates for 2009 by region and for the United States. We also present the percentage point change since 2007 and 2008, with statistically significant changes indicated $\left({ }^{*} \mathrm{p}<0.05\right)$. Poverty determination is based on the U.S. Office of Management and Budget income thresholds, which vary by family composition. In 2009, the poverty line for a family of four (two adults, two children) was $\$ 21,756$. $^{4}$

\section{Key Findings}

- Nearly 5.7 million children under age 6 live in poverty in America. Over one million of these poor young children live in rural America.

- More than one in four young children living in rural America was in poverty in 2009.

- Poverty among young children increased significantly since 2007 in the rural Northeast, Midwest, and South, and in the suburban places of each region. In all regions, rural poverty is greater than that in the suburbs but lower than in the central cities, except in the West, where rates are similar to those experienced in urban places.

- In the urban Midwest and West, young child poverty significantly increased between 2008 and 2009 and between 2007 and 2009.

- Young children's likelihood of living in poverty increased the most in the rural and urban Midwest, where the poverty rate increased by 4.4 and 3.4 percentage points, respectively, over the past two years.

- Young children in the rural South remain the most likely to be poor, with one out of three children living in poverty.

- Young children were more likely to be poor than all children in the rural and suburban areas of all regions and urban areas in the South, Midwest, and West.

- The number of young children in poverty did not decline in any urban, suburban, or rural regional breakdown since 2008, and many areas saw increases in the number of children under age 6 living in poverty. 


\begin{tabular}{|c|c|c|c|c|c|c|c|c|c|c|c|c|c|c|c|}
\hline & \multicolumn{15}{|c|}{2009 AMERICAN COMMUNITY SURVEY } \\
\hline & \multicolumn{5}{|c|}{ RURAL } & \multicolumn{5}{|c|}{ SUBURBAN } & \multicolumn{5}{|c|}{ CENTRAL CITY } \\
\hline & $\begin{array}{l}\text { Population } \\
\text { under age } \\
6 \text { for whom } \\
\text { poverty is } \\
\text { determined }\end{array}$ & $\begin{array}{c}\text { Below } \\
\text { poverty }\end{array}$ & $\begin{array}{l}\text { Percent } \\
\text { below } \\
\text { poverty }\end{array}$ & $\begin{array}{c}\text { Percent } \\
\text { Change } \\
\text { Since 2008 }\end{array}$ & $\begin{array}{c}\text { Percent } \\
\text { Change } \\
\text { Since 2007 }\end{array}$ & $\begin{array}{l}\text { Population } \\
\text { under age } \\
6 \text { for whom } \\
\text { poverty is } \\
\text { determined }\end{array}$ & $\begin{array}{c}\text { Below } \\
\text { poverty }\end{array}$ & $\begin{array}{l}\text { Percent } \\
\text { below } \\
\text { poverty }\end{array}$ & $\begin{array}{c}\text { Percent } \\
\text { Change } \\
\text { Since } 2008\end{array}$ & $\begin{array}{c}\text { Percent } \\
\text { Change } \\
\text { Since 2007 }\end{array}$ & $\begin{array}{c}\text { Population } \\
\text { under age } \\
6 \text { for whom } \\
\text { poverty is } \\
\text { determined }\end{array}$ & $\begin{array}{c}\text { Below } \\
\text { poverty }\end{array}$ & $\begin{array}{l}\text { Percent } \\
\text { below } \\
\text { poverty }\end{array}$ & $\begin{array}{c}\text { Percent } \\
\text { Change } \\
\text { Since 2008 }\end{array}$ & $\begin{array}{l}\text { Percent } \\
\text { Change } \\
\text { Since } 2007\end{array}$ \\
\hline United States & $3,686,503$ & $1,054,998$ & 28.6 & $2.1^{*}$ & $2.9^{*}$ & $12,400,000$ & $2,135,888$ & 17.2 & $1.8^{*}$ & $2.4^{*}$ & $8,703,139$ & $2,489,511$ & 28.6 & $2.0^{*}$ & $1.8^{\star}$ \\
\hline Northeast & 329,245 & 72,618 & 22.1 & 1.3 & $3.2^{*}$ & $2,307,448$ & 289,513 & 12.5 & 1.4 & $2.1^{*}$ & $1,314,817$ & 382,989 & 29.1 & 1.6 & -0.8 \\
\hline Midwest & $1,102,241$ & 280,483 & 25.5 & $2.7^{*}$ & $4.4^{*}$ & $2,488,582$ & 381,659 & 15.3 & $1.9^{*}$ & $2.4^{*}$ & $1,625,236$ & 519,537 & 32.0 & $3.1^{*}$ & $3.4^{*}$ \\
\hline South & $1,704,913$ & 568,292 & 33.3 & $2.2^{*}$ & $2.3^{*}$ & $4,667,293$ & 924,346 & 19.8 & $2.0^{*}$ & $2.4^{*}$ & $3,077,449$ & 942,840 & 30.6 & 1.6 & 1.3 \\
\hline West & 550,104 & 133,605 & 24.3 & 1.1 & 1.5 & $2,956,469$ & 540,370 & 18.3 & 1.7 & $2.6^{*}$ & $2,685,637$ & 644,145 & 24.0 & $2.0^{*}$ & $2.8^{*}$ \\
\hline
\end{tabular}

${ }^{1} \mathrm{P}<0.05$

${ }^{2}$ Levels of urbanization are defined as follows: rural consists of ACS geographic components "not in metropolitan or micropolitan statistical area" and "in micropolitan statistical area," suburban includes "in metropolitan statistical area-not in principal city," and central city includes "in metropolitan statistical area-in principal city."

${ }^{3}$ Data are based on 2009 American Community Survey estimates. For corresponding margins of error, refer to the U.S. Census American Community Survey.

${ }^{4}$ Percentage point changes are based on unrounded poverty percentages and may differ slightly from those that would be obtained using rounded figures.

Earlier this month, the U.S. Census Bureau released nationwide estimates of poverty. These data suggest the poverty rate, at 14.3 percent, is up from 2008 and at its highest since 1994. There are an estimated 43.6 million people living in poverty, the most since measurement began over fifty years ago. The rate for children is up to 20.7 percent, an increase of 1.7 percentage points since $2008,{ }^{5}$ a total increase of 2.7 percentage points since 2007 when the rate was 18 percent. Children were the age group most likely to be poor; in 2009, an estimated 15.5 million children were poor. They comprise 35.5 percent of the poor but are only 24.5 percent of the total population, according to the U.S. Census Bureau report. The report also indicates a rise in the poverty rate for young children. While 21.3 percent of young children were poor in 2008 , this reached 23.8 percent, or nearly one in four, in 2009. The ACS samples approximately three million households in the United States each year, whereas the Current Population Survey (CPS), the source for poverty data released earlier this month, relies upon fewer than 100,000 households monthly. With its larger sample size, the ACS data allow examination of the poverty rate by state and place. ${ }^{6}$

Table 2 shows estimated child poverty numbers and rates for each state, region, and the nation by place. These differences are likely driven by a host of factors not captured here, including the demographics of the population (race, single motherhood, parental education and employment, and so on) and local characteristics, including access to services, housing quality, social capital, and job market conditions. Again, we present the percentage point change since 2007 and 2008 , with statistically significant changes indicated $\left({ }^{*} \mathrm{p}<0.05\right)$.
Table 2 highlights the differences in child poverty rates.

- Children under age 18 are most likely to be poor in rural Mississippi, Arizona, South Carolina, Kentucky, urban Ohio, Michigan, Pennsylvania, Mississippi, Tennessee, and Georgia. More than three in ten children in these places are poor.

- Children under age 18 are least often poor in suburban America, where estimated poverty rates are below 10 percent in thirteen states. Rates are also very low in rural Connecticut, Nevada, and New Hampshire, and in urban Wyoming.

- In seven states, Alaska, Arizona, Florida, Kentucky, North Carolina, Oregon, and Washington, rural child poverty rates exceed those in urban places. In an additional twenty-two states, rural child poverty rates are similar to urban rates; suburban child poverty did not exceed rural child poverty in any place except suburban Nevada.

- Across the United States, rural child poverty rates increased significantly over the past two years. Rural child poverty rates increased in every region except the Northeast.

- Rural child poverty increased in fourteen states between 2007 and 2009. Increases were also evident in the suburbs in twenty states and in urban places in thirteen states during these years. 
TABLE 2. CHILD POVERTY BY PLACE SIZE IN 2009

\begin{tabular}{|c|c|c|c|c|c|c|c|c|c|c|c|c|c|c|c|}
\hline \multirow[b]{3}{*}{ United States } & \multicolumn{5}{|c|}{ RURAL } & \multicolumn{5}{|c|}{ SUBURBAN } & \multicolumn{5}{|c|}{ CENTRAL CITY } \\
\hline & $\begin{array}{l}\text { Population } \\
\text { under age } 18 \text { for } \\
\text { whom poverty } \\
\text { is determined }\end{array}$ & $\begin{array}{c}\text { Below } \\
\text { poverty }\end{array}$ & $\begin{array}{l}\text { Percent } \\
\text { below } \\
\text { poverty }\end{array}$ & $\begin{array}{c}\text { Percent } \\
\text { Point } \\
\text { Change } \\
\text { Since 2008 }\end{array}$ & $\begin{array}{c}\text { Percent } \\
\text { Point } \\
\text { Change } \\
\text { Since 2007 }\end{array}$ & $\begin{array}{l}\text { Population } \\
\text { under age } 18 \text { for } \\
\text { whom poverty } \\
\text { is determined }\end{array}$ & $\begin{array}{c}\text { Below } \\
\text { poverty }\end{array}$ & $\begin{array}{c}\text { Percent } \\
\text { below } \\
\text { poverty }\end{array}$ & $\begin{array}{c}\text { Percent } \\
\text { Point } \\
\text { Change } \\
\text { Since 2008 }\end{array}$ & $\begin{array}{c}\text { Percent } \\
\text { Point } \\
\text { Change } \\
\text { Since 2007 }\end{array}$ & $\begin{array}{c}\text { Population } \\
\text { under age } 18 \text { for } \\
\text { whom poverty is } \\
\text { determined }\end{array}$ & $\begin{array}{c}\text { Below } \\
\text { poverty }\end{array}$ & $\begin{array}{l}\text { Percent } \\
\text { below } \\
\text { poverty }\end{array}$ & $\begin{array}{c}\text { Percent } \\
\text { Point } \\
\text { Change } \\
\text { Since 2008 }\end{array}$ & $\begin{array}{c}\text { Percent } \\
\text { Point } \\
\text { Change } \\
\text { Since 2007 }\end{array}$ \\
\hline & $11,300,000$ & $2,734,167$ & 24.2 & $1.9^{*}$ & $2.3^{*}$ & $38,300,000$ & $5,661,376$ & 14.8 & $1.6^{*}$ & $1.9^{*}$ & $23,700,000$ & $6,261,419$ & 26.4 & $2.0^{*}$ & $1.7^{\star}$ \\
\hline Alabama & 311,741 & 97,388 & 31.2 & $4.9^{*}$ & $3.9^{*}$ & 498,537 & 85,142 & 17.1 & 1.7 & -3.3 & 303,501 & 92,376 & 30.4 & 2.1 & 2.2 \\
\hline Alaska & 43,550 & 7,835 & 18.0 & 0.9 & -1.6 & 39,734 & 3,990 & 10.0 & 1.4 & $1.1^{*}$ & 82,619 & 9,580 & 11.6 & 2.5 & 2.2 \\
\hline Arizona & 129,364 & 43,734 & 33.8 & $5.9^{*}$ & 2.8 & 734,589 & 124,814 & 17.0 & 0.9 & 1.2 & 840,531 & 229,512 & 27.3 & $3.5^{*}$ & $5.0^{*}$ \\
\hline Arkansas & 264,302 & 80,408 & 30.4 & 3.2 & 1.5 & 224,641 & 48,620 & 21.6 & 2.9 & 0.7 & 207,796 & 60,170 & 29.0 & 0.2 & 1.9 \\
\hline California & 168,832 & 34,115 & 20.2 & -1.6 & 1.8 & $4,774,959$ & 862,841 & 18.1 & $1.7^{*}$ & $2.9^{*}$ & $4,341,501$ & 949,785 & 21.9 & $1.3^{*}$ & $2.4^{*}$ \\
\hline Colorado & 151,987 & 29,668 & 19.5 & $6.0^{*}$ & 0.8 & 607,525 & 73,493 & 12.1 & 1.5 & 0.8 & 452,372 & 107,337 & 23.7 & 1.9 & 1.1 \\
\hline Connecticut & 65,109 & 6,383 & 9.8 & -0.8 & 2.3 & 510,240 & 42,689 & 8.4 & 0.2 & 0.7 & 224,329 & 47,821 & 21.3 & -1.8 & 1.0 \\
\hline Delaware & 39,318 & 6,903 & 17.6 & -2.8 & 3.9 & 140,466 & 19,405 & 13.8 & 3.3 & 2.3 & 23,469 & 7,200 & 30.7 & 9.8 & -4.8 \\
\hline Florida & 210,059 & 62,230 & 29.6 & 1.9 & $8.1^{*}$ & $2,752,961$ & 530,117 & 19.3 & $2.4^{*}$ & $4.1^{*}$ & $1,031,144$ & 259,456 & 25.2 & $4.7^{*}$ & $3.8^{*}$ \\
\hline Georgia & 438,523 & 137,408 & 31.3 & $4.4^{*}$ & $5.5^{*}$ & $1,697,302$ & 299,883 & 17.7 & $1.8^{*}$ & $2.7^{*}$ & 408,907 & 131,033 & 32.0 & 1.7 & -0.5 \\
\hline Hawaii & 87,745 & 12,665 & 14.4 & 3.5 & 3.1 & 134,250 & 19,314 & 14.4 & $5.6^{*}$ & $4.4^{*}$ & 62,253 & 7,262 & 11.7 & 0.1 & 4.6 \\
\hline Idaho & 140,599 & 26,644 & 19.0 & -1.7 & 1.3 & 156,179 & 23,439 & 15.0 & 3.1 & 1.8 & 116,941 & 24,925 & 21.3 & $6.1^{*}$ & 4.2 \\
\hline Illinois & 355,501 & 80,657 & 22.7 & $3.3^{*}$ & $5.3^{*}$ & $1,717,874$ & 223,508 & 13.0 & $1.6^{*}$ & $2.0^{*}$ & $1,057,475$ & 287,233 & 27.2 & 1.6 & 1.4 \\
\hline Indiana & 331,751 & 68,271 & 20.6 & 1.0 & $2.6^{*}$ & 745,584 & 95,872 & 12.9 & 0.2 & 1.3 & 481,426 & 146,888 & 30.5 & $4.7^{*}$ & $5.3^{*}$ \\
\hline Iowa & 295,862 & 46,072 & 15.6 & -0.6 & 0.8 & 201,668 & 17,736 & 8.8 & 1.2 & $2.5^{*}$ & 199,650 & 45,615 & 22.8 & 4.1 & 3.6 \\
\hline Kansas & 209,118 & 40,300 & 19.3 & 2.4 & 2.4 & 255,271 & 28,194 & 11.0 & $3.5^{*}$ & 2.2 & 224,632 & 52,901 & 23.6 & $4.4^{*}$ & $5.2^{*}$ \\
\hline Kentucky & 409,432 & 130,686 & 31.9 & 3.0 & 2.6 & 359,444 & 67,491 & 18.8 & 2.1 & $1.5^{*}$ & 229,054 & 57,239 & 25.0 & 0.4 & 0.5 \\
\hline Louisiana & 288,580 & 85,842 & 29.7 & 0.9 & $-4.1^{*}$ & 500,822 & 94,135 & 18.8 & 1.4 & -0.8 & 317,484 & 88,059 & 27.7 & $-4.7^{*}$ & $-3.8^{*}$ \\
\hline Maine & 107,321 & 21,085 & 19.6 & 2.0 & 1.2 & 116,751 & 13,487 & 11.6 & 0.6 & -0.4 & 40,000 & 10,618 & 26.5 & -0.2 & 8.4 \\
\hline Maryland & 65,847 & 9,806 & 14.9 & 1.3 & 3.9 & $1,039,730$ & 91,599 & 8.8 & 0.8 & 0.9 & 225,218 & 52,644 & 23.4 & 4.2 & 1.9 \\
\hline Massachusetts & N/A & N/A & $\mathrm{N} / \mathrm{A}$ & N/A & N/A & $1,085,743$ & 107,292 & 9.9 & 1.0 & 0.9 & 324,778 & 78,321 & 24.1 & 1.3 & -1.8 \\
\hline Michigan & 386,924 & 88,122 & 22.8 & $2.5^{*}$ & $3.2^{*}$ & $1,272,068$ & 189,931 & 14.9 & $2.0^{*}$ & $2.4^{*}$ & 651,214 & 241,775 & 37.1 & $4.6^{*}$ & $3.7^{*}$ \\
\hline Minnesota & 294,936 & 47,397 & 16.1 & $2.3^{*}$ & $2.7^{*}$ & 655,757 & 59,685 & 9.1 & $1.7^{*}$ & 0.7 & 287,554 & 66,898 & 23.3 & $4.8^{*}$ & $3.5^{*}$ \\
\hline Mississippi & 414,722 & 156,926 & 37.8 & 2.9 & 2.7 & 247,770 & 46,757 & 18.9 & -2.2 & 1.9 & 88,340 & 28,945 & 32.8 & -2.8 & -3.2 \\
\hline Missouri & 339,315 & 89,421 & 26.4 & 1.9 & $4.8^{*}$ & 770,609 & 116,133 & 15.1 & 2.6 & $2.4^{*}$ & 294,886 & 85,405 & 29.0 & 1.1 & 3.0 \\
\hline Montana & 140,697 & 31,291 & 22.2 & 0.1 & 1.9 & 26,780 & 2,962 & 11.1 & -3.1 & -0.4 & 49,114 & 12,145 & 24.7 & 4.7 & 7.7 \\
\hline Nebraska & 172,719 & 26,032 & 15.1 & 1.3 & -1.0 & 92,935 & 7,546 & 8.1 & -0.6 & -0.0 & 169,778 & 32,771 & 19.3 & 2.9 & 0.6 \\
\hline Nevada & 49,261 & 5,361 & 10.9 & -1.6 & -3.0 & 317,269 & 51,893 & 16.4 & 2.8 & $3.3^{*}$ & 288,754 & 57,040 & 19.8 & 2.7 & 2.2 \\
\hline New Hampshire & 89,176 & 9,934 & 11.1 & -1.7 & 2.3 & 142,675 & 10,333 & 7.2 & $3.1^{*}$ & 1.9 & 43,352 & 8,780 & 20.3 & 3.1 & 2.7 \\
\hline New Jersey & N/A & N/A & N/A & N/A & N/A & $1,805,776$ & 211,635 & 11.7 & $1.3^{*}$ & $2.2^{*}$ & 219,942 & 61,062 & 27.8 & -0.9 & -1.6 \\
\hline New Mexico & 178,046 & 43,185 & 24.3 & -3.4 & -3.5 & 155,696 & 43,483 & 27.9 & $5.6^{*}$ & 2.4 & 173,400 & 41,443 & 23.9 & 1.6 & 0.9 \\
\hline New York & 318,715 & 66,869 & 21.0 & 0.5 & 1.5 & $1,881,155$ & 192,118 & 10.2 & 1.1 & $1.6^{*}$ & $2,151,977$ & 609,367 & 28.3 & 0.9 & -0.3 \\
\hline North Carolina & 636,433 & 182,994 & 28.8 & $3.6^{*}$ & $4.4^{*}$ & 897,511 & 159,622 & 17.8 & $2.3^{*}$ & $3.7^{*}$ & 705,736 & 162,321 & 23.0 & 2.0 & 0.8 \\
\hline North Dakota & 71,890 & 10,886 & 15.1 & -1.0 & -0.2 & 27,026 & 1,521 & 5.6 & $-7.2^{*}$ & -2.3 & 40,740 & 5,741 & 14.1 & -1.4 & 0.2 \\
\hline Ohio & 521,126 & 119,506 & 22.9 & $3.3^{*}$ & $4.3^{*}$ & $1,513,156$ & 221,369 & 14.6 & $3.1^{*}$ & $2.5^{*}$ & 639,445 & 243,435 & 38.1 & $3.3^{*}$ & $3.6^{*}$ \\
\hline Oklahoma & 317,200 & 80,373 & 25.3 & -1.0 & 0.1 & 332,160 & 52,025 & 15.7 & 0.1 & 0.2 & 253,683 & 68,225 & 26.9 & -0.1 & -1.0 \\
\hline Oregon & 181,564 & 44,284 & 24.4 & 2.3 & 3.2 & 397,629 & 64,540 & 16.2 & 0.6 & 1.9 & 277,862 & 55,502 & 20.0 & 1.0 & 2.1 \\
\hline Pennsylvania & 407,767 & 70,963 & 17.4 & -0.9 & 0.6 & $1,727,273$ & 193,079 & 11.2 & 0.0 & $1.2^{*}$ & 588,334 & 202,596 & 34.4 & 2.4 & -0.2 \\
\hline Rhode Island & N/A & N/A & N/A & N/A & N/A & 149,461 & 22,796 & 15.3 & 2.8 & 2.4 & 74,228 & 14,935 & 20.1 & -1.8 & -6.3 \\
\hline South Carolina & 242,134 & 81,166 & 33.5 & $7.1^{*}$ & $7.4^{*}$ & 653,270 & 130,119 & 19.9 & 1.3 & 2.1 & 166,054 & 48,144 & 29.0 & 2.0 & 3.1 \\
\hline South Dakota & 100,584 & 22,641 & 22.5 & 1.2 & 1.2 & 36,869 & 3,116 & 8.5 & 0.2 & 2.5 & 54,248 & 9,740 & 18.0 & -0.1 & 2.0 \\
\hline Tennessee & 370,300 & 92,748 & 25.0 & 0.2 & -1.3 & 589,773 & 93,344 & 15.8 & $3.0^{*}$ & 0.9 & 506,422 & 163,759 & 32.3 & 2.4 & 2.4 \\
\hline Texas & 736,940 & 199,496 & 27.1 & 1.0 & 0.4 & $2,866,225$ & 533,348 & 18.6 & $1.9^{*}$ & 1.4 & $3,198,381$ & 928,558 & 29.0 & $1.8^{*}$ & 1.0 \\
\hline Utah & 93,785 & 15,314 & 16.3 & 2.3 & -1.0 & 612,769 & 56,764 & 9.3 & 0.8 & 1.2 & 154,284 & 32,922 & 21.3 & $5.3^{*}$ & 3.3 \\
\hline Vermont & 80,986 & 12,146 & 15.0 & 1.0 & 0.1 & 34,141 & 3,178 & 9.3 & 0.3 & 2.5 & N/A & N/A & N/A & $\mathrm{N} / \mathrm{A}$ & N/A \\
\hline Virginia & 228,278 & 49,989 & 21.9 & -0.3 & 2.5 & $1,135,885$ & 108,498 & 9.6 & 0.3 & 0.6 & 452,094 & 94,581 & 20.9 & 0.6 & 1.4 \\
\hline Washington & 177,063 & 41,193 & 23.3 & 3.1 & 3.2 & 920,683 & 125,336 & 13.6 & 2.1 & 1.3 & 448,337 & 84,301 & 18.8 & 0.9 & 0.1 \\
\hline West Virginia & 164,263 & 47,914 & 29.2 & 2.8 & 2.9 & 169,016 & 29,015 & 17.2 & -0.7 & -0.8 & 42,131 & 11,681 & 27.7 & -1.9 & -0.9 \\
\hline Wisconsin & 324,750 & 51,727 & 15.9 & 1.0 & 1.6 & 591,093 & 56,468 & 9.6 & $1.7^{*}$ & $1.5^{*}$ & 368,659 & 106,209 & 28.8 & $7.8^{*}$ & $3.9^{*}$ \\
\hline Wyoming & 87,818 & 11,405 & 13.0 & 2.4 & -0.7 & N/A & N/A & N/A & N/A & N/A & 26,536 & 2,859 & 10.8 & -0.9 & 3.8 \\
\hline Northeast & $1,082,937$ & 188,935 & 17.4 & -0.0 & 1.1 & $7,453,215$ & 796,607 & 10.7 & $0.9^{*}$ & $1.5^{*}$ & $3,676,007$ & $1,034,671$ & 28.1 & 0.8 & -0.4 \\
\hline Midwest & $3,404,476$ & 691,032 & 20.3 & $1.9^{*}$ & $2.9^{*}$ & $7,879,910$ & $1,021,079$ & 13.0 & $1.9^{*}$ & $2.0^{*}$ & $4,469,707$ & $1,324,611$ & 29.6 & $3.5^{*}$ & $3.1^{*}$ \\
\hline South & $5,138,072$ & $1,502,277$ & 29.2 & $2.4^{*}$ & $2.5^{*}$ & $14,100,000$ & $2,389,120$ & 16.9 & $1.7^{*}$ & $1.8^{*}$ & $8,271,950$ & $2,287,524$ & 27.7 & $1.8^{*}$ & $1.3^{*}$ \\
\hline West & $1,660,480$ & 351,923 & 21.2 & $1.4^{*}$ & 1.0 & $8,890,633$ & $1,454,570$ & 16.4 & $1.7^{*}$ & $2.2^{*}$ & $7,314,504$ & $1,614,613$ & 22.1 & $1.8^{*}$ & $2.5^{*}$ \\
\hline
\end{tabular}

$\mathrm{N} / \mathrm{A}=$ Not applicable

${ }^{1} \mathrm{P}<0.05$

${ }^{2}$ Levels of urbanization are defined as follows: rural consists of ACS geographic components "not in metropolitan or micropolitan statistical area" and "in micropolitan statistical area," suburban includes "in metropolitan statistical area-not in principal city," and central city includes "in metropolitan statistical area-in principal city."

${ }^{3}$ Data are based on 2009 American Community Survey estimates. For corresponding margins of error, refer to the U.S. Census American Community Survey.

${ }^{4}$ Percentage point changes are based on unrounded poverty percentages and may differ slightly from those that would be obtained using rounded figures.

5 Places where the percent point change since 2008 is significant but the change since 2007 is not significant experienced declines in the child poverty rate from 2007 to 2008 , except suburban North Dakota, where poverty significantly increased from 2007 to 2008 and declined in 2009. 
While the official poverty measure is one important indicator of the well-being of America's children, several limitations of the measure may mask the true experiences of the nation. The poverty threshold considers all reported sources of income and cash transfers but excludes the benefit of such programs as income tax credits (for example, the Earned Income Tax Credit (EITC) and the Child Tax Credit) and the Supplemental Nutrition Assistance Program (SNAP). Estimates from the recently released CPS data suggest that if the EITC were weighed, 2.2 million fewer children would be considered below the poverty threshold. ${ }^{7}$ When net income after all taxes and credits are considered, this number rises to 2.9 million. Estimates also suggest that SNAP benefits lift 1.7 million children out of poverty. The official poverty measure does include cash transfers such as unemployment insurance benefits and social security income. U.S. Census Bureau estimates suggest unemployment benefits kept one million children out of poverty, and social security kept 1.1 million children above the poverty threshold. ${ }^{8}$ These estimates highlight the crucial role of programs to support and assist low-income families.

Rising child poverty indicates a need for policies that focus on children, particularly in the early years. While it may be tempting to cut services to children and families during this "Great Recession," this is a time when policies need to target these groups and do a better job of assisting those who are in poverty. Additionally, since this recession is not over and we have seen dramatic declines in income, many families above the poverty line may need additional support to remain afloat. Investing in children is an essential priority to ensure their long-term outcomes and the future success of the generation. Renewing the provisions provided for in the American Recovery and Reinvestment Act may be an important first step, but other measures to address child poverty and focus on poverty reduction are also important. While the Obama administration has taken important steps to assist struggling families, there is still immense work to be done at both the federal and state levels. Keeping poverty reduction as a top policy priority will enhance the well-being of America's children.

\section{Data}

This analysis is based upon U.S. Census Bureau estimates from the 2007, 2008, and 2009 ACS. For more details or information, please refer to the U.S. Census American Community Survey. ${ }^{9}$ Tables were produced by aggregating information from detailed tables available on American FactFinder (http://factfinder.census.gov/home/saff/main. html?_lang=en). These estimates are meant to give perspective on child poverty, but since they are based on survey data, caution must be used in comparing across years or places, as the margin of error may indicate that seemingly disparate numbers fall within sampling error. ${ }^{10}$ Regional differences highlighted in this brief are statistically significant $(\mathrm{p}<0.05)$. 


\section{E N D N O T E S}

1. Jeanne Brooks-Gunn and Greg. J. Duncan, “The effects of poverty on children," The Future Of Children / Center For The Future Of Children, The David And Lucile Packard Foundation, 7 (1997): 55-71; See also Robert H. Bradley et al., "The home environments of children in the United States part I: Variations by age, ethnicity, and poverty status," Child Development, 72 (2001): 1844-1886.

2. See Anne Case, Angela Fertig, and Christina Paxson, “The lasting impact of childhood health and circumstance," Journal of Health Economics 24 (2005): 365-389, who examined the impact of prenatal conditions and child health at age 7 on various outcomes; and Vonnie C. McLoyd, "Socioeconomic disadvantages and child development," American Psychologist, 53 (1998): 185-204.

3. See Robert Greenstein's statement on the U.S. Census Bureau's 2009 poverty and health insurance data: http://www. cbpp.org/cms/index.cfm?fa=view\&id=3292.

4. See http://www.census.gov/hhes/www/poverty/about/ overview/measure.html, and also see "U.S. Census Bureau, September 2010 Poverty: 2009 Highlights."

5. See U.S. Census Bureau, September 2010 Poverty: 2009 Highlights, Income, Poverty, and Health Insurance Coverage: 2009, at http://www.census.gov/prod/2010pubs/p60-238. pdf, and also see http://www.census.gov/hhes/www/poverty/ about/overview/index.html.

6. See https://www.census.gov/acs/www/Downloads/survey_ methodology/acs_design_methodology_ch04.pdf, http:// cps.ipums.org/cps/sample_sizes.shtml, and http://www. census.gov/prod/2006pubs/tp-66.pdf.

7. See U.S. Census Bureau, September 2010 Poverty: 2009 Highlights, Income, Poverty, and Health Insurance Coverage: 2009, at http://www.census.gov/prod/2010pubs/p60-238.pdf.

8. Estimates are presented in the U.S. Census Bureau PowerPoint for the Press Release, accessed at http://www.census. gov/newsroom/releases/pdf/09-16-10_slides.pdf.

9. See http://factfinder.census.gov/servlet/

DTGeoSearchByListServlet?ds_name=ACS_2007_3YR_ G00_\&_lang=en\&_ts=268570514748.

10. Refer to the U.S. Census Bureau's published tables for detailed margins of error.
ABOUT THE AUTHORS

Marybeth J. Mattingly is director of research on vulnerable families at the Carsey Institute and a research assistant professor of sociology at the University of New Hampshire (beth.mattingly@unh.edu).

Michelle L. Stransky is a doctoral candidate in sociology at the University of New Hampshire and a research assistant at the Carsey Institute(mlu6@cisunix.unh.edu).

\section{A C K N O W L E D G M E N T S}

The authors thank Jess Bean, Mil Duncan, Terri Rippett, Andrew Schaefer, and Amy Sterndale at the Carsey Institute for their assistance, comments, and suggestions. 


\section{$\triangle$ UNIVERSITY - of NEW HAMPSHIRE}

\section{CARSEY}

Building knowledge for families and communities

The Carsey Institute conducts policy research on vulnerable children, youth, and families and on sustainable community development. We give policy makers and practitioners timely, independent resources to effect change in their communities.

This work was supported by the Annie E. Casey Foundation, the W. K. Kellogg Foundation, and anonymous.

Huddleston Hall

73 Main Street

Durham, NH 03824

(603) $862-2821$

www.carseyinstitute.unh.edu 